\title{
Comparative study between pony mares and ewes evaluating gonadotrophic response to administration of gonadotrophin-releasing hormone
}

\author{
M. B. Porter ${ }^{1}$, B. D. Cleaver ${ }^{1}$, M. Peltier ${ }^{1}$, G. Robinson ${ }^{1}$, \\ W. W. Thatcher ${ }^{2}$ and D. C. Sharp ${ }^{1 *}$ \\ ${ }^{1}$ Department of Animal Science and ${ }^{2}$ Department of Dairy Science, University of Florida, Gainesville, \\ FL 32611, USA
}

This study compared equine and ovine LH secretory responses to GnRH treatment. Dioestrous mares and ewes were challenged with continuous GnRH for $15 \mathrm{~h}$. Mares that received constant $\mathrm{GnRH}\left(110 \mu \mathrm{g} \mathrm{h}^{-1}\right)$ had sustained $\mathrm{LH}$ secretion $(P<0.01)$, whereas $\mathrm{LH}$ concentrations in ewes treated with continuous $\mathrm{GnRH}\left(25 \mu \mathrm{g} \mathrm{h}^{-1}\right)$ initially increased, then declined and remained low, suggesting GnRH receptor desensitization or downregulation. In addition, progesterone-primed, ovariectomized mares and ewes were challenged with pulsatile or continuous GnRH for 5 days. Plasma LH concentrations were increased by day 5 in mares treated with pulsatile $\left(25 \mu \mathrm{g}\right.$ pulse $\left.{ }^{-1} \mathrm{~h}^{-1}\right)$ and continuous $\left(110 \mu \mathrm{g} \mathrm{h}^{-1}\right) \mathrm{GnRH}$ $(P<0.01)$. Furthermore, mean LH concentrations and time-response curves were not different. In contrast, ewes treated with continuous GnRH $\left(2.5 \mu \mathrm{g} \mathrm{h}^{-1}\right)$ demonstrated $\mathrm{LH}$ secretory patterns indicative of GnRH receptor downregulation on day 1 of treatment. $\mathrm{LH}$ concentrations in ewes treated with pulsatile GnRH (250 ng pulse ${ }^{-1} h^{-1}$ ) did not differ from controls. In conclusion, pony mares responded continuously to GnRH treatment (pulsatile and continuous), whereas ewes treated with continuous GnRH experienced reduced $\mathrm{LH}$ secretion. These findings suggest a unique hypothalamic-pituitary axis in pony mares.

\section{Introduction}

GnRH and LH secretion has been described as rhythmically pulsatile in various species, including sheep (Clarke and Cummins, 1982) and primates (Dierschke et al., 1970). In rodents, humans and sheep, exogenous administration of GnRH must be pulsatile to match endogenous $\mathrm{GnRH}$ release, providing normal physiological stimulation of $\mathrm{LH}$ (Santen and Bardin, 1973; Levine and Ramirez 1980; Moenter et al., 1992). Conversely, continuous $\mathrm{GnRH}$ administration causes reduced LH release owing to GnRH receptor desensitization or downregulation (Nett et al., 1981; Crowder et al., 1986). Receptor desensitization is described as a loss of receptor binding owing to continuous ligand stimulation which may reflect physical or chemical changes within the receptor or second messenger system. These changes reduce its affinity for the ligand, thus preventing continued release of the target hormone (Dohlman et al., 1991; Lerrant et al., 1995). In contrast, receptor downregulation is a loss of receptor binding owing to a reduction in the number of receptors, which causes a reduction in target hormone release (Clayton, 1989; Dohlman et al., 1991). The reduction in the number of receptors may be due, in part, to alterations in receptor synthesis (Lerrant et al., 1995),

*Correspondence.

Revised manuscript received 20 January 1997. degradation (Chedrese et al., 1994), recycling (Valiquette et al., 1990), or post-receptor modifications (Dohlman et al., 1991). Although downregulation and desensitization of the GnRH receptor have been described in other species, they have not been described in horses. Furthermore, some studies evaluating gonadotrophin response to administration of $\mathrm{GnRH}$ suggest that mares may be resistant to $\mathrm{GnRH}$ receptor downregulation (Garcia and Ginther, 1975; Turner and Irvine, 1991). Therefore, we proposed to compare the LH response, as an indicator of receptor downregulation and desensitization, in sheep and horses, to continuous or pulsatile administration of $\mathrm{GnRH}$.

\section{Materials and Methods}

\section{Materials}

Progesterone (4-pregnene-3,20-dione; Sigma P-1030, Sigma Chemical Company) was dissolved in benzyl alcohol (Fisher Scientific A396-500, Fisher Scientific, Pittsburgh, PA) and diluted to the desired concentration $\left(25 \mathrm{mg} \mathrm{ml}^{-1}\right)$ in sesame oil (Sigma S-7131) (benzyl alcohol:sesame oil, 1:10). Progesterone implants were supplied by E. D. Plotka, Marshfield Medical Research Foundation, Marshfield, WI. Peripheral concentrations of progesterone ranged from 2.0 to $5.0 \mathrm{ng} \mathrm{ml}^{-1}$ within 1 week of implantation, consistent with previously published data 
concerning mid-luteal concentrations of progesterone in sheep (Quirk ef al., 1979).

Natural GnRH (BACHEM H-4005, purity HPLC >99\%, BACHEM BioScience Inc., King of Prussia, PA) was solubilized in sterile $0.9 \%(\mathrm{w} / \mathrm{v}) \mathrm{NaCl}$ and diluted to the desired concentration in $0.9 \%$ saline. GnRH solutions were stored at $-20^{\circ} \mathrm{C}$.

Portable peristaltic pumps (Peristaltic Technologies, Inc., Mineoli, NY, Portable Pulsatile Drug Delivery Device, Model 1500; 5 ounces, $2.5 \mathrm{~cm} \times 2.75 \mathrm{~cm} \times 1 \mathrm{~cm}$ ) were validated in this laboratory to deliver $50 \mu \mathrm{l}$ of fluid pulse ${ }^{-1} \mathrm{~h}^{-1}$ for $48 \mathrm{~h}$. When set to constant infusion, pumps infused $50 \mu \mathrm{lmin}^{-1}$. A $9 \mathrm{~V}$ battery was required for each pump and needed replacement every $24 \mathrm{~h}$. The life of a $9 \mathrm{~V}$ battery exceeded $24 \mathrm{~h}$ in the validation test, but the battery was replaced every $24 \mathrm{~h}$ during the experiment as a precaution.

\section{Experiment I (mares)}

During August, eight pony mares were selected from a resident herd. Mares had experienced normal oestrous cycles throughout the two preceding months, as monitored by daily teasing with a pony stallion, rectal palpation and rectal ultrasonography. All mares received $5 \mathrm{mg}$ (i.m.) of prostaglandin $\mathrm{F}_{2 \alpha}$ (Lutalyse; UpJohn, Kalamazoo, MI) to synchronize oestrus. Mares were separated randomly into two groups 10-12 days after ovulation: group 1 , control mares $(n=4)$; and group 2, GnRH-treated mares $(n=4)$. On the day of treatment, control mares were infused with isotonic saline continuously for $15 \mathrm{~h}$ while the treatment mares were infused with isotonic saline for the first $2 \mathrm{~h}$ and then with $\mathrm{GnRH}\left(110 \mu \mathrm{g} \mathrm{h}^{-1}\right)$ for the remaining $13 \mathrm{~h}$. The dose of $\mathrm{GnRH}(110 \mu \mathrm{g})$ to be infused was based on studies by Becker and Johnson (1992), who infused $20 \mu \mathrm{g}$ of $\mathrm{GnRH}$ in either a pulsatile or continuous fashion. We wished to challenge the equine pituitary and evaluate the LH secretory response to acute $(13 \mathrm{~h})$ administration of $\mathrm{GnRH}$ at supraphysiological concentrations. Automatic syringe pumps (Harvard Apparatus Co. Inc., South Natick, MA), calibrated to deliver $10 \mathrm{ml} \mathrm{h}^{-1}$, were used. Mares were fitted with intravenous catheters (Angiocath; 14 gauge $\times 5.25 \mathrm{in}$ ) in left and right jugular veins and blood samples were collected from the contralateral jugular vein every $15 \mathrm{~min}$.

\section{Experiment I (ewes)}

During December, eight cyclic Rambouillet ewes were selected from a residential flock. Normal oestrous cycles were observed in all ewes before the experiment. Ewes were selected to be 10-12 days after oestrus and were assigned randomly to two groups: group 1, control ewes $(n=4)$; and group 2, GnRH-treated ewes $(n=4)$. On the day of treatment, group 1 ewes were infused with isotonic saline continuously for $15 \mathrm{~h}$, whereas Group 2 ewes were infused with isotonic saline for the first $2 \mathrm{~h}$ and then natural GnRH $\left(25 \mu \mathrm{g} \mathrm{h}^{-1}\right)$ for $13 \mathrm{~h}$. The dose of GnRH was determined based on studies by Nett et al. (1981). They administered GnRH at $2.5 \mu \mathrm{g} \mathrm{h}^{-1}$ and noted attenuation of $\mathrm{LH}$ secretion which suggested receptor desensitization. As in Expt I with mares, we wished to examine the $\mathrm{LH}$ response in ewes to acute administration of $\mathrm{GnRH}$ at supraphysiological concentrations. All animals were fitted with intravenous jugular vein catheters in both right and left jugular veins and were housed in holding crates throughout the infusion period. Infusion pumps, infusion rates and infusion periods were similar to Expt I (mares). However, jugular blood samples were collected every $10 \mathrm{~min}$ rather than every $15 \mathrm{~min}$.

\section{Experiment 2 (mares)}

Six adult ovariectomized pony mares were selected during May. Experiment 2 was designed as two replicates, separated by a 2 week recovery period, to maximize the number of mares in each group. To lower plasma LH to dioestrous concentrations before treatment, all mares received progesterone (75 mg per injection, i.m.) twice a day for 10 days before and throughout the treatment period. Five days before beginning treatment, subcutaneous tygon jugular vein catheters were installed. The catheters extended subcutaneously from the jugular vein to the prescapular region. Two days after catheter placement, girth straps carrying portable peristaltic pumps were fitted on all mares, and infusion lines from the pumps were connected to the subcutaneous tygon catheter at the exit point near the withers. The portable pumps were protected in a plastic housing so that the mares were free to move about their enclosure throughout the experiment except during sampling hours.

Mares were assigned randomly, in each replicate, to one of three groups: group 1, saline treated ( $n=2)$; group 2, constant GnRH (25 $\left.\mu \mathrm{g} \mathrm{h}^{-1}, n=2\right)$; and group 3, pulsatile GnRH (25 $\mu \mathrm{g}$ pulse ${ }^{-1} h^{-1}, n=2$ ). The dose was significantly lower than that used in Expt 1 because we wished to evaluate the gonadotrophic response to chronic (5 days) administration of physiological concentrations of GnRH. On the morning of sampling period 1 (day $0 ; 1$ day before onset of treatment), mares were fitted with intravenous sampling catheters in the jugular vein opposite the infusion jugular vein and blood samples were collected every $15 \mathrm{~min}$ for $8 \mathrm{~h}$. Sampling catheters were left in place overnight for use the next day. On the next day (day 1 of treatment), peristaltic pumps were charged with $\mathrm{GnRH}$ solution for pulsatile infusion $(25 \mu \mathrm{g}$ per $50 \mu \mathrm{l}$ pulse ${ }^{-1} \mathrm{~h}^{-1}$; group 3), constant GnRH solution ( $25 \mu \mathrm{g}$ per $3 \mathrm{ml}$; group 2) or isotonic saline (group 1). Peristaltic pumps were validated in this laboratory to deliver $50 \mu$ l fluid pulse ${ }^{-1}$ $\mathrm{h}^{-1}$ for $48 \mathrm{~h}$. Group 1 mares (control) were randomly assigned to receive either constant saline or hourly pulses of saline. Treatment began on day $I$ and blood samples were collected at $15 \mathrm{~min}$ intervals for $8 \mathrm{~h}$ as on day 0 . After collection of the last sample, the sampling catheters were removed and all infusion reservoirs were refilled. Mares were monitored every $12 \mathrm{~h}$ on days 2, 3 and 4 to administer progesterone, collect blood samples (once per day), refill infusion reservoirs, replace the pump battery and for health management. On day 5 of treatment, mares were refitted with intravenous jugular vein catheters for collection of blood samples. Blood samples were collected every $15 \mathrm{~min}$ for $8 \mathrm{~h}$, as on days 0 and 1 . At the end of day 5 , progesterone injections were terminated, sampling catheters were removed, portable pumps were turned off and girth straps removed. Subcutaneous infusion catheters were left in place throughout the 2 week recovery period and were 
flushed daily with heparinized saline (Heparin (sodium salt) Sigma H-9399, Sigma Chemical Company, St Louis, MO). Catheter exit sites were examined daily and were treated with Furazolidone spray. At the end of the 2 week recovery period, administration of progesterone twice per day was resumed and maintained for 10 days before the onset of treatment and throughout the treatment period (days 1-5). The protocol described for replicate 1 was repeated in replicate 2 .

\section{Experiment 2 (ewes)}

Nine adult, ovariectomized Rambouillet ewes were selected from a resident flock during December. Two weeks before the onset of treatment all ewes had subcutaneous progesterone implants surgically placed in the axillary region. Two days before sampling period 1, intravenous catheters were fitted in both jugular veins of all ewes. One jugular vein was used for sampling and the contralateral jugular vein was used for infusion of GnRH. Tygon catheter extensions were connected to jugular vein catheters (infusion catheter) and extended to portable peristaltic infusion pumps. Ewes were assigned randomly to three groups: group 1, control $(n=3)$; group 2, constant GnRH (2.5 $\left.\mu \mathrm{g} \mathrm{h}^{-1}, n=3\right)$; and group 3, pulsatile GnRH (250 ng pulse ${ }^{-1} \mathrm{~h}^{-1}, n=3$ ). As for mares in Expt 2, GnRH concentrations (pulsatile and constant) were decreased from Expt $I$ and the treatment period was prolonged ( 5 days) to evaluate the LH secretory response to chronic physiological stimulation. Blood samples were collected from all ewes 1 day before the onset of treatment (day 0 ), on day 1 of treatment and on day 5 of treatment for $8 \mathrm{~h}$ at $10 \mathrm{~min}$ intervals. Ewes were examined every $12 \mathrm{~h}$ on days 2,3 and 4 and pump reservoirs were refilled, batteries replaced, and blood samples were collected each day.

\section{Experiment 3 (mares)}

Five weeks after the end of Expt 2, the same pony mares were used in Expt 3. As in Expt 2, all mares received progesterone ( $75 \mathrm{mg}$ every $12 \mathrm{~h}$, i.m.) for 10 days before day 1 of treatment and progesterone administration continued throughout the treatment period. Mares were assigned randomly to two groups: group 1 , control (no treatment, $n=4$ ); and group 2, constant GnRH $\left(100 \mu \mathrm{g} \mathrm{h}^{-1}\right)(n=4)$. Five days before treatment, group 2 mares had subcutaneous tygon catheters surgically placed, as in Expt 2 . Two days later, group 2 mares were fitted with girth straps carrying portable peristaltic pumps. As in Expt 2, mares were sampled I day before the onset of treatment (day 0 ) and samples were collected at $15 \mathrm{~min}$ intervals for $8 \mathrm{~h}$. Sampling protocol was repeated on day 1 of treatment and day 5 of treatment. In addition, blood samples were collected every $24 \mathrm{~h}$ on all days of treatment (days 1-5).

All animal work in all experiments was approved and regulated by the IACUC at the University of Florida.

\section{Portable pump pack}

Portable peristaltic pumps were housed in customized packs able to support the weight of the animal while allowing it to move around freely while being treated. Plastic, electrical junction boxes $(10 \mathrm{~cm} \times 10 \mathrm{~cm})$ were lined with closed cell foam padding to fit the pump device and reservoir. A plastic cover was fastened with four screws. The junction box was placed within a rubber inner tube (inner diameter $10 \mathrm{~cm}$ ) and secured in place by inflating the inner tube. Duct tape was used to protect the inner tube from abrasion. Four holes were drilled into the cover of the junction box to prevent pump overheating. The distal end of the jugular catheter was connected via the 23 gauge needle hub to Silastic tubing (Dow Corp.) from the peristaltic pump. Infusion reservoirs were custom made from sealable plastic bags to hold approximately $45 \mathrm{ml}$. Tygon tubing leading out from the reservoir was sealed with silicon adhesive and connected to Silastic tubing used in the peristaltic pump. All tubing and reservoir bags were gas (NO) sterilized before use. The portable pack was fastened to a girth strap such that the pack was lateral to the spinal column, and a breast strap (5 $\mathrm{cm}$ nylon webbing) was used to prevent the girth strap from moving caudally. The girth strap was padded with $10 \mathrm{~cm}$ cotton webbing to minimize friction. Daily adjustments were made to maintain proper pack position.

\section{Hormone assays of blood samples}

Approximately $8-10 \mathrm{ml}$ of blood was collected into heparinized tubes and stored at $2^{\circ} \mathrm{C}$ until plasma was separated by centrifugation at 3000 r.p.m. for 15 min. Plasma was stored at $-20^{\circ} \mathrm{C}$. $\mathrm{LH}$ content was measured by radioimmunoassay. Equine $\mathrm{LH}$ was analysed by radioimmunoassay as described by Thompson et al. (1983) using rabbit antiserum to ECG provided by $\mathrm{D}$. Thompson, Louisiana State University, Baton Rouge, LA. Sheep anti-rabbit immunoglobins were supplied by Sigma Chemical Company and purified equine LH was provided by J. Roser, University of California, Davis, CA. The assay sensitivity, intra- and interassay coefficients of variation were $1.2 \mathrm{ng} \mathrm{ml}^{-1}, 4.5 \%$ and $4.6 \%$, respectively. Ovine LH was measured with a polyclonal antibody (NIADDK-oLH-I-2) supplied by the National Hormone and Pituitary Program, Ogden BioServices Corp., Rockville, MD. The assay sensitivity, intraand interassay coefficients of variation were $0.40 \mathrm{ng} \mathrm{ml}^{-1}$, $7.2 \%$ and $4.6 \%$, respectively. Ovine and equine progesterone concentrations were measured in plasma using a commercial solid phase radioimmunoassay kit (TKPG5) provided by Diagnostic Products Corp, Los Angeles, CA. The assay sensitivity, intra- and interassay coefficients of variation were $0.5 \mathrm{ng}$ $\mathrm{ml}^{-1}, 4.3 \%$ and $4.5 \%$, respectively.

\section{Statistical analysis}

Data from Expts 1, 2 and 3 were analysed using the Statistical Analysis System (SAS). A split-plot design with repeated measures was used in a least squares analysis of variance (ANOVA) to test for differences among treatment groups, and orthogonal contrasts of least square means were used to compare treatment groups and treatment group-by-day interactions. Tests for homogeneity of regression were performed on time-response curves representing treatment-byday-by-sample interactions. In addition, LH concentrations in 
blood samples collected each day were analysed by ANOVA and effects of treatment and treatment-by-day interactions were tested. Tests for homogeneity of regression among daily samples (time-response curves) were also performed.

Data from individual animals were analysed by cluster pulse analysis (Veldhuis and Johnson, 1986) for evidence of significant LH peaks. Each LH peak was defined by specific criteria: (1) an increase in LH concentration must have exceeded preceding $\mathrm{LH}$ values by a factor at least equal to the sensitivity of the assay; (2) the increase must have exceeded the mean LH concentrations plus two times the intra-assay coefficient of variation; and (3) each LH peak must consist of three consecutive points in time. Average peak interval, peak width and peak amplitude were measured and analysed using least square analysis of variance and orthogonal contrasts.

\section{Results}

\section{Experiment 1 (mares)}

Mean plasma progesterone concentrations were not different between group 1 mares $\left(8.0 \pm 0.6 \mathrm{ng} \mathrm{m}^{-1}\right)$ and group 2 $\left(8.6 \pm 0.6 \mathrm{ng} \mathrm{ml}^{-1}\right)$ mares. The concentrations corresponded to mid-luteal phase concentrations as described by Sharp and Black (1973). However, group 2 mares (continuous GnRH) had significantly higher $(P<0.009)$ concentrations of plasma $\mathrm{LH}$ $\left(26.38 \pm 3.94 \mathrm{ng} \mathrm{ml}^{-1}\right.$ least square means $\pm \mathrm{SD}$ ) than group 1 mares (control; $10.00 \pm 2.97 \mathrm{ng} \mathrm{ml}^{-1}$ ). Tests for homogeneity of regression indicated that the time-response curves representing each treatment were not parallel. This was due to an increase in plasma LH in group 2 (Fig. 1a), after the onset of GnRH treatment, and maintenance of plasma LH concentrations above baseline for the remainder of the infusion. Plasma LH concentrations in group I remained at baseline throughout the experiment.

Cluster analysis of LH peak number, interval, width and amplitude did not indicate differences in number of peaks, peak width or peak interval. However, LH peak amplitude was lower $(P<0.01)$ in mares treated with continuous $\mathrm{GnRH}(15.75 \pm$ $\left.5.00 \mathrm{ng} \mathrm{ml}{ }^{-1}\right)$ than in control mares $\left(45.0 \pm 5.0 \mathrm{ng} \mathrm{ml}^{-1}\right.$; Table 1).

\section{Experiment 1 (ewes)}

Mean progesterone concentrations did not differ between ewes in group $1\left(2.8 \pm 1.6 \mathrm{ng} \mathrm{ml}^{-1}\right)$ and ewes in group 2 $\left(3.6 \pm 1.3 \mathrm{ng} \mathrm{ml}{ }^{-1}\right)$. LH concentrations in group 2 ewes (continuous $\mathrm{GnRH}, 25 \mu \mathrm{g} \mathrm{h}^{-1}$ ) were significantly higher (15.47 $\left.\pm 1.97 \mathrm{ng} \mathrm{ml}^{-1} ; P<0.004\right)$ than $\mathrm{LH}$ concentrations in group 1 ewes (continuous saline; $0.997 \pm 2.80 \mathrm{ng} \mathrm{ml}^{-1}$ ). Plasma LH concentrations in group 2 were not maintained above baseline throughout the infusion but returned to baseline after $9 \mathrm{~h}$ of $\mathrm{GnRH}$ infusion (Fig. Ib). Time-response curves for each treatment were tested for homogeneity of regression and the curves were not parallel $(P<0.01)$. LH concentrations did not differ between groups for the first $2 \mathrm{~h}$ of sampling. However, $10 \mathrm{~min}$ after the onset of $\mathrm{GnRH}$ infusion, $\mathrm{LH}$ concentrations increased sharply in group 2 and continued to
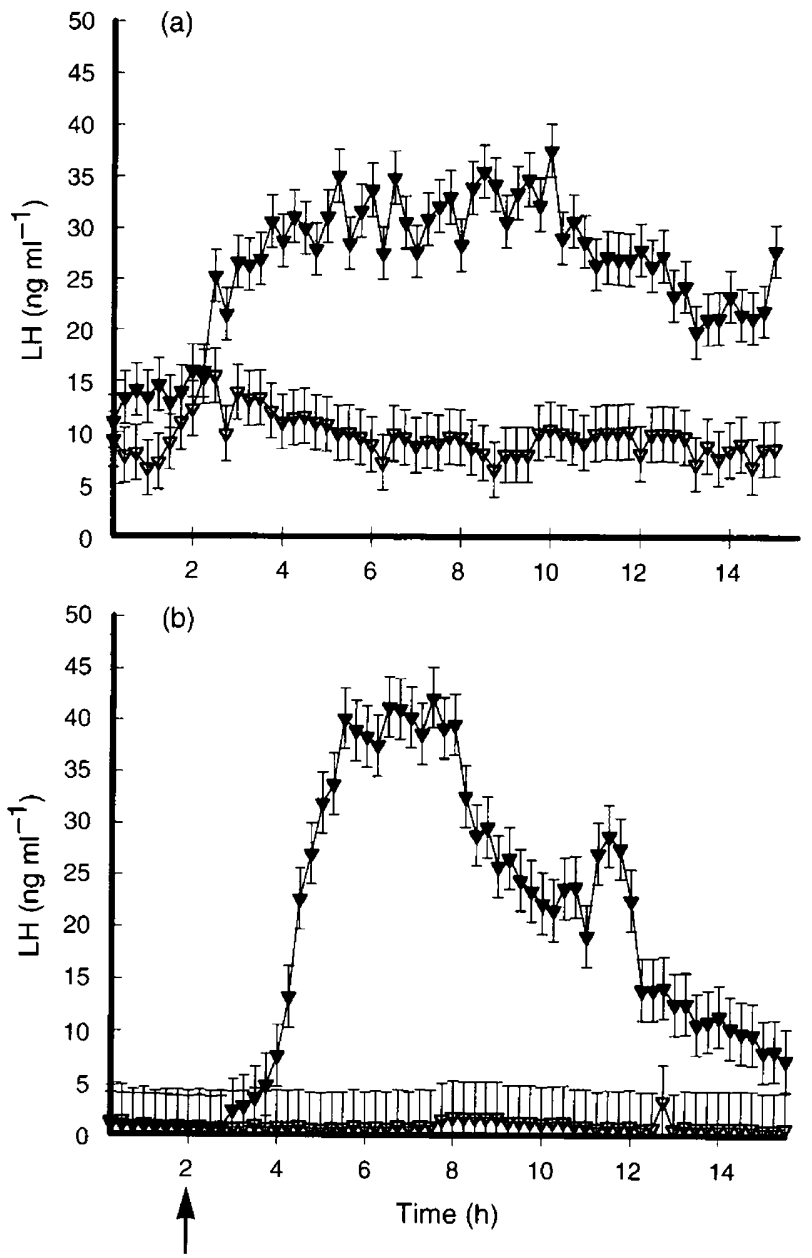

Fig. 1. Time-response curves representing plasma $\mathrm{LH}$ concentrations (least square means $\pm \mathrm{SD}$ ) in mares (a) and ewes (b) treated with GnRH (Expt 1). (a) LH patterns in samples collected from mares every $15 \mathrm{~min}$ for $15 \mathrm{~h}$. The curves representing control mares $(\nabla)$ and mares treated with continuous GnRH ( $\mathbf{\nabla})$ were not parallel $(P<0.01)$. (b) LH patterns in samples collected from ewes every $10 \mathrm{~min}$ for $15 \mathrm{~h}$. The curves representing control ewes $(\nabla)$ and ewes treated with continuous GnRH ( $\mathbf{\nabla})$ were not parallel $(P<0.01)$. The arrow indicates the time at which GnRH infusion began.

rise for approximately $2.5 \mathrm{~h}$. After $2.5 \mathrm{~h}$ of $\mathrm{GnRH}$ infusion, $\mathrm{LH}$ concentrations reached a plateau for $2.25 \mathrm{~h}$ and subsequently declined. Plasma concentrations of $\mathrm{LH}$ returned to near baseline concentrations in group 2 ewes within $6 \mathrm{~h}$ of reaching maximum concentrations. An apparent short-lived increase was observed in plasma concentrations of LH in group 2 approximately $9 \mathrm{~h}$ after onset of $\mathrm{GnRH}$ infusion. This was attributed to a brief rise and subsequent decline in plasma LH in two of the four ewes (Fig. 1b).

Cluster analysis of LH peak number, interval, width and amplitude did not indicate differences in $\mathrm{LH}$ peak interval or LH peak width. However, the number of $\mathrm{LH}$ peaks in group 2 ewes $(1.75 \pm 0.5)$ was significantly lower $(P<0.01)$ than in group 1 ewes $(4.7 \pm 0.6$; Table 1$)$. In addition, the LH peak amplitude was significantly greater $(P<0.01)$ in ewes treated with constant $\mathrm{GnRH}\left(48.5 \pm 6.0 \mathrm{ng} \mathrm{ml}{ }^{-1}\right)$ compared with control ewes $\left(2.10 \pm 7.0 \mathrm{ng} \mathrm{ml}^{-\mathrm{I}}\right)$. 
Table 1. Mean $( \pm S D)$ number of $\mathrm{LH}$ peaks in $15 \mathrm{~h}$, peak interval, peak width and peak amplitude as determined by ANOVA

\begin{tabular}{lccccc}
\hline Group & Species & $\begin{array}{c}\text { Number of } \\
\text { LH peaks }\end{array}$ & $\begin{array}{c}\text { LH peak } \\
\text { interval (min) }\end{array}$ & $\begin{array}{c}\text { LH peak } \\
\text { width (min) }\end{array}$ & $\begin{array}{c}\text { LH peak amplitude } \\
\text { (ng ml }\end{array}$ \\
\hline Control & Mare & $2.25 \pm 0.75$ & $155 \pm 50.0$ & $323.0 \pm 131.0$ & $45.0 \pm 5.0$ \\
Constant GnRH & Mare & $2.25 \pm 0.75$ & $315.8 \pm 35.0$ & $205.0 \pm 113.0$ & $15.75 \pm 5.0^{*}$ \\
Control & Ewe & $4.67 \pm 0.6$ & $146 \pm 24$ & $106 \pm 38$ & $2.1 \pm 7.0$ \\
Constant GnRH & Ewe & $1.75 \pm 0.6^{*}$ & $100 \pm 29$ & $206 \pm 38$ & $48.5 \pm 6.0^{*}$ \\
\hline
\end{tabular}

*Significantly different from control $(P<0.01)$.

\section{Experiment 2 (mares)}

Progesterone concentrations did not differ across replicates or between treatment groups or days of treatment. Plasma concentrations of progesterone were $7.54 \pm 0.99 \mathrm{ng} \mathrm{ml}^{-1}$ (replicate 1) and $9.15 \pm 1.02 \mathrm{ng} \mathrm{ml}^{-1}$ (replicate 2), similar to progesterone concentrations measured during dioestrus in Expt 1 (mares). Mean LH concentrations measured during the multiple sampling periods (days 0,1 and 5) were significantly higher $(P<0.04)$ in group 3 (pulsatile $\mathrm{GnRH}$ ) than in group 1 (control) and group 2 (constant GnRH). Furthermore, plasma LH concentrations were greater $(P<0.01)$ in group 3 (pulsatile $\mathrm{GnRH}$ ) by day 5 of treatment than they were in group 2 (constant GnRH) or group 1 (control) (Fig. 2a).

Time-response curves representing $\mathrm{LH}$ concentrations measured on each of the multiple sampling days (days 0,1 and 5) were tested for homogeneity of regression and were not parallel. Regression analysis of group 2 mares alone indicated that the day $5 \mathrm{LH}$ time-response curve differed from that of day 0 and day $I(P<0.001)$.

Mean plasma concentrations of $\mathrm{LH}$ were significantly lower $(P<0.02)$ in control mares and constant $\mathrm{GnRH}$ mares than in pulsatile GnRH mares on days 4 and 5 of treatment (Fig. 3a). Furthermore, tests for homogeneity of regression indicated that the time-response curves (treatment-by-day) were not parallel.

Cluster analysis of LH peak number, interval, width and amplitude in all groups across all days revealed no differences in LH peak interval or width. However, there were significantly fewer peaks on day 5 in control mares $(1.5 \pm 0.76 ; P<0.01)$ compared with mares treated with pulsatile GnRH $(3.9 \pm 0.76)$ and continuous $\mathrm{GnRH}(4.5 \pm 0.76)$. The number of LH peaks

Fig. 2. Mean plasma LH concentrations (least square means \pm SD) in progesterone-treated, ovariectomized mares $(a, b)$ and ewes (c) treated with pulsatile ( $\mathbf{a})$ and constant (四) GnRH (Expt $2(a, c)$ and Expt 3 (b)), representing treatment-by-day interactions ( $\square$, control). Samples were collected every $15 \mathrm{~min}$ for $8 \mathrm{~h}$. (a) Plasma LH collected from mares in Expt 2. ANOVA indicated that plasma $\mathrm{LH}$ concentrations were significantly $\left({ }^{*} P<0.01\right)$ higher on day 5 in pulsatile $\mathrm{GnRH}$ treated mares $\left(25 \mu \mathrm{g}\right.$ pulse $\left.e^{-1} \mathrm{~h}^{-1}\right)$ than in control and constant GnRH-treated mares $\left(25 \mu \mathrm{g} \mathrm{h}^{-1}\right)$. (b) Plasma LH collected from mares in Expt 3. ANOVA indicated that plasma $\mathrm{LH}$ concentrations in constant GnRH-treated mares $\left(100 \mu \mathrm{g} \mathrm{h}^{-1}\right)$ were higher $(P<0.01)$ on day 5 than in control mares. (c) Plasma LH collected from ewes in Expt 2. ANOVA indicated that plasma LH concentrations in constant GnRH-treated ewes $\left(2.5 \mu \mathrm{g} \mathrm{h}^{-1}\right)$ were higher $\left({ }^{*} P<0.01\right)$ on day 1 than controls or pulsatile GnRH-treated ewes. did not differ between constant GnRH mares and pulsatile GnRH mares on day 5. In addition, LH peak amplitude was significantly greater $(P<0.01)$ on day 5 in mares treated with
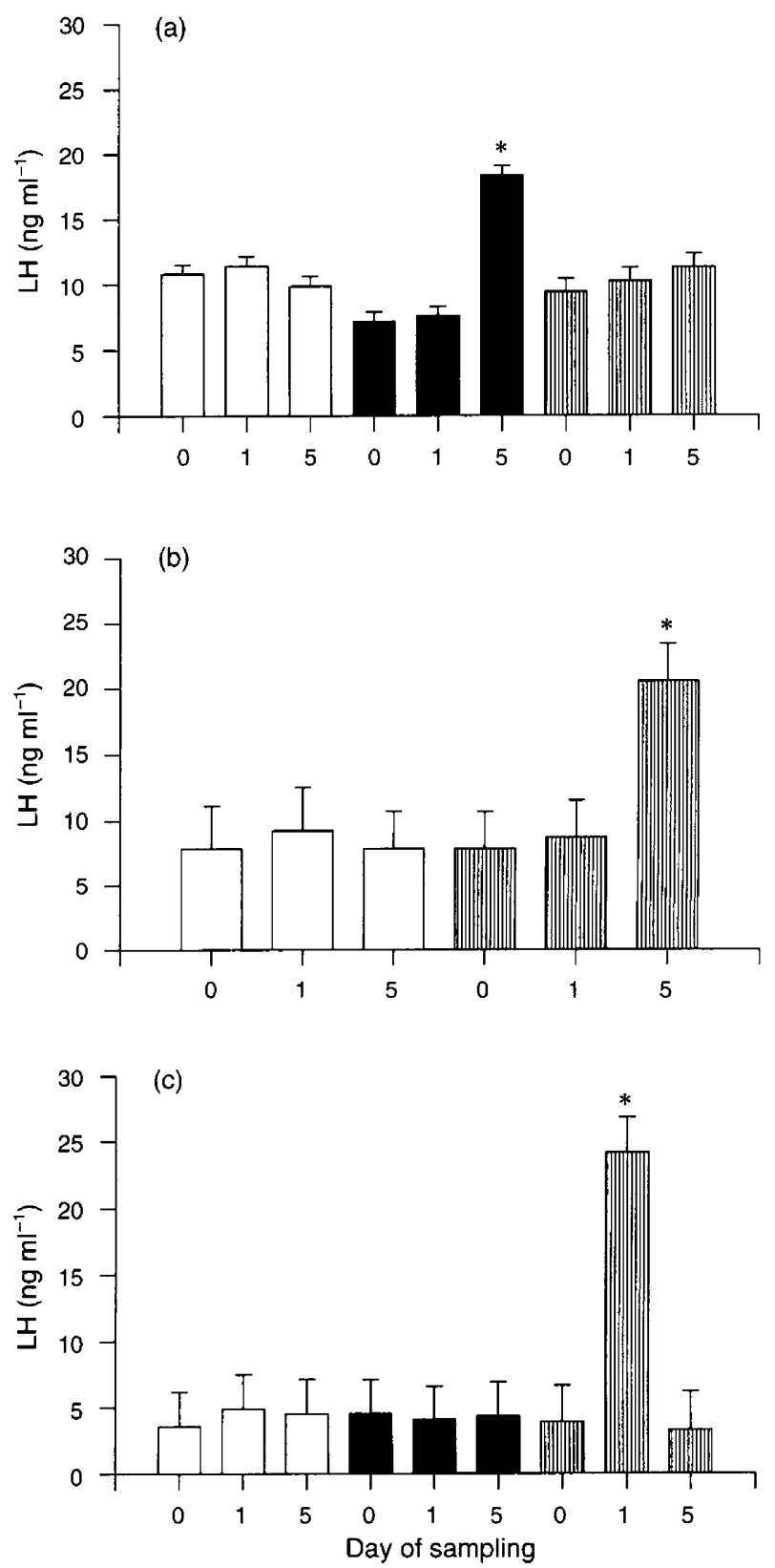

Downloaded from Bioscientifica.com at 04/26/2023 01:29:05PM via free access 

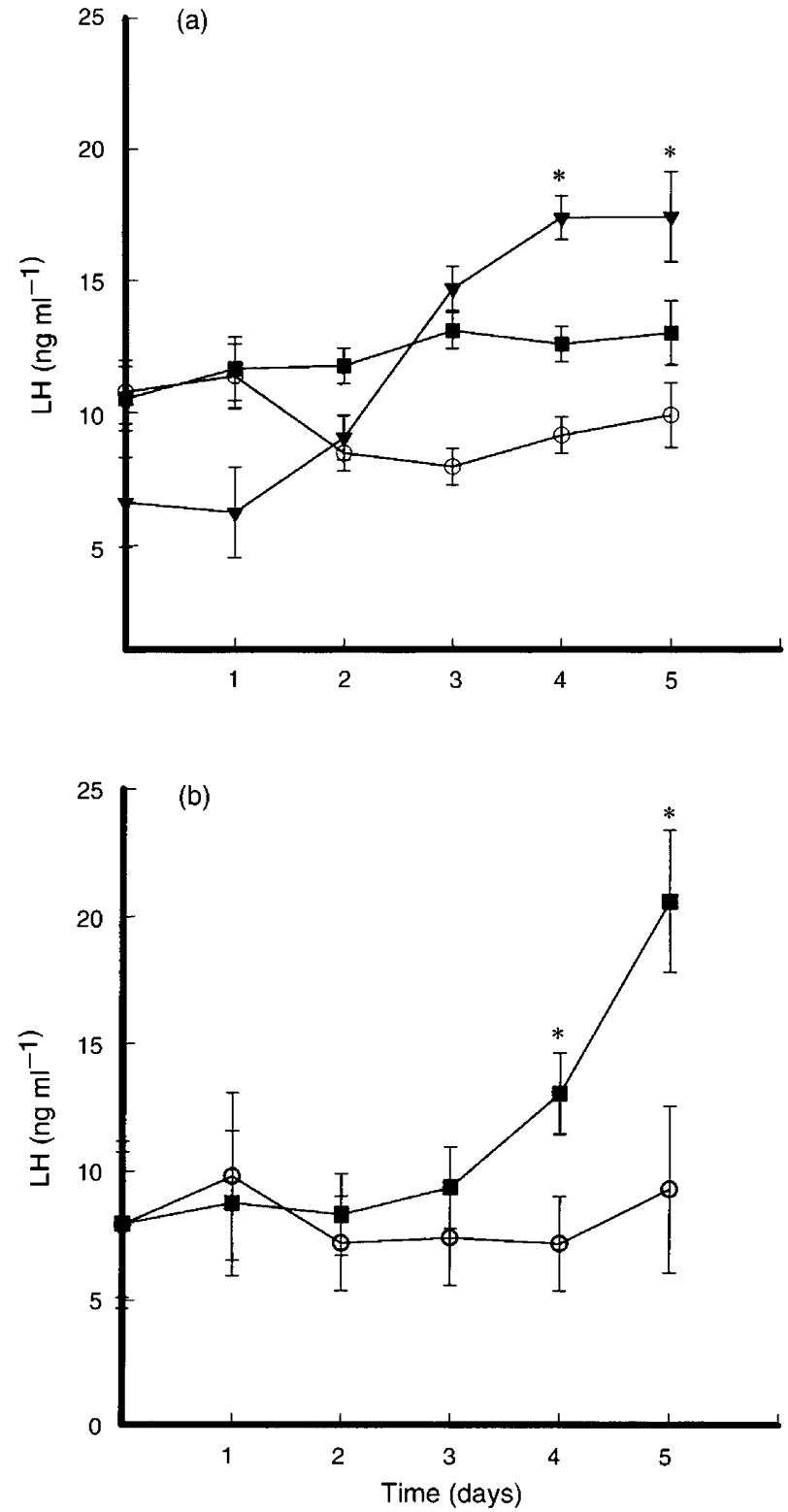

Fig. 3. Time-response curves representing plasma LH collected from progesterone-treated, ovariectomized mares treated with pulsatile $(\boldsymbol{\nabla})$ and constant ( $\boldsymbol{\square}) \mathrm{GnRH}$ from day 0 to day 5 of treatment (treatment began on day $I ; O$, control). (a) LH time trends measured in mares during Expt 2. The curve representing mares treated with pulsatile $\mathrm{GnRH}$ was not parallel to the curves representing control mares and mares treated with constant $\mathrm{GnRH}$, owing to the increase $\left({ }^{*} P<0.02\right)$ in LH secretion on day 4 and 5 in mares treated with pulsatile GnRH. (b) LH time trends measured in mares during Expt 3. The curve representing mares treated with constant $\mathrm{GnRH}$ was not parallel to the curve representing control mares, owing to the increase in LH concentrations $\left({ }^{*} P<0.01\right)$ on day 4 and 5 in mares treated with continuous GnRH.

pulsatile $\mathrm{GnRH}\left(22.50 \pm 30 \mathrm{ng} \mathrm{ml}^{-1}\right)$ compared with control mares $\left(11.12 \pm 1.4 \mathrm{ng} \mathrm{ml}^{-1}\right)$ and mares treated with constant GnRH (14.67 $\pm 0.93 \mathrm{ng} \mathrm{ml}^{-1}$ ) (Table 2). LH secretory patterns from representative mares (Fig. 4b,d) suggest increased LH basal secretion on day 5 in pulsatile GnRH-treated mares. However, the LH secretory pattern remained episodic.
Experiment 2 (ewes)

LH concentrations were higher $(P<0.01)$ in group 2 (constant $\mathrm{GnRH} ; 24.12 \pm 2.63 \mathrm{ng} \mathrm{ml}^{-1}$ ) than in group 3 ewes $\left(4.02 \pm 2.54 \mathrm{ng} \mathrm{ml}^{-1}\right)$ and control ewes (4.49 $\left.\pm 2.61 \mathrm{ng} \mathrm{ml}^{-1}\right)$ on day 1 of treatment. Orthogonal contrasts also indicated that plasma LH concentrations increased from day 0 to day $I$ in group 2 whereas there was no change in group $3(P<0.01)$. Furthermore, LH concentrations in group 2 decreased from day 1 to day 5 , yet there was no change in group $3 \mathrm{LH}$ concentrations (Fig. 2c).

Tests for homogeneity of regression indicated that the timeresponse curves representing treatment-by-day-by-sample interactions ( $\mathrm{LH}$ concentrations measured during multiple sampling periods) were not parallel. These differences may be due primarily to the initial increase and subsequent decrease of plasma LH concentrations in group 2 ewes throughout day $I$.

Cluster analysis indicated a significant reduction $(P<0.02)$ in mean number of $\mathrm{LH}$ peaks on days $\mathrm{I}$ and 5 in ewes treated with constant GnRH (3.30 \pm 0.84 and $3.70 \pm 0.84$, respectively) compared with day $0(6.70 \pm 0.84)$. There were no differences noted in mean LH peak interval; however, the peak width and amplitude were significantly greater $(P<0.001)$ on day 1 in ewes treated with constant GnRH $(88.0 \pm 9.2 \mathrm{~min}$ and $52.3 \pm 5.2 \mathrm{ng} \mathrm{ml}^{-1}$, respectively) compared with control ewes $\left(54.41 \pm 12.20 \mathrm{~min}\right.$ and $\left.7.54 \pm 7.0 \mathrm{ng} \mathrm{ml}^{-1}\right)$ and pulsatile $\mathrm{GnRH}$ ewes $\left(35.7 \pm 9.2 \mathrm{~min}\right.$ and $7.4 \pm 5.2 \mathrm{ng} \mathrm{ml}^{-1}$ ) (Table 2). LH secretory patterns from representative ewes (Fig. 4a) suggest a regular periodic release of LH in control animals. Continuous GnRH appears to disrupt this pattern, causing a marked increase in $\mathrm{LH}$ secretion followed by a decrease and lack of response to $\mathrm{GnRH}$ administration (Fig. 4e). In contrast, pulsatile $\mathrm{GnRH}$ appeared to maintain the periodic $\mathrm{LH}$ release (Fig. 4c).

\section{Experiment 3 (mares)}

Regression analysis of $\mathrm{LH}$ time trends from mares treated with continuous GnRH in Expt 2 indicated that on day 5 the time trends were different from those on day 0 and day 1 . Thus, although mean concentrations of $\mathrm{LH}$ were different between pulsatile and continuous GnRH-treated mares, the data suggested an LH response that may have been minimal owing to the dose of GnRH administered. Therefore, in Expt 3, mares were treated with a dose of $\mathrm{GnRH}$ that was approximately four times more concentrated (100 $\mathrm{gg}$ of $\mathrm{GnRH}$ per

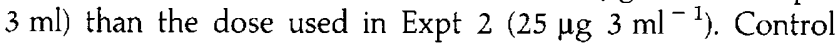
animals were not treated with isotonic saline because of the improbability of stimulating an $\mathrm{LH}$ response by infusing $\mathrm{NaCl}$ indicated in Expt 2.

Mean LH concentrations measured during the multiple sampling periods were significantly greater $(P<0.01)$ on day 5 in group $2\left(20.57 \pm 3.98 \mathrm{ng} \mathrm{ml}^{-1}\right)$ than in group I $(9.29 \pm$ $4.50 \mathrm{ng} \mathrm{ml}^{-1}$ ) (Fig. 2b). Time-response curves were analysed for homogeneity of regression and were not parallel. Timeresponse curves representing $\mathrm{LH}$ daily samples also were not parallel owing to the rise in LH concentrations in group 2 mares on days 4 and 5 of treatment (Fig. 3b).

There were no differences in mean number of LH peaks, peak interval or peak width between group 1 and group 2 across the 
Table 2. Mean $( \pm \mathrm{SD})$ number of $\mathrm{LH}$ peaks in $8 \mathrm{~h}$, peak interval, peak width and peak amplitude $\left(\mathrm{ng} \mathrm{ml}^{-1}\right.$ ) as determined by ANOVA

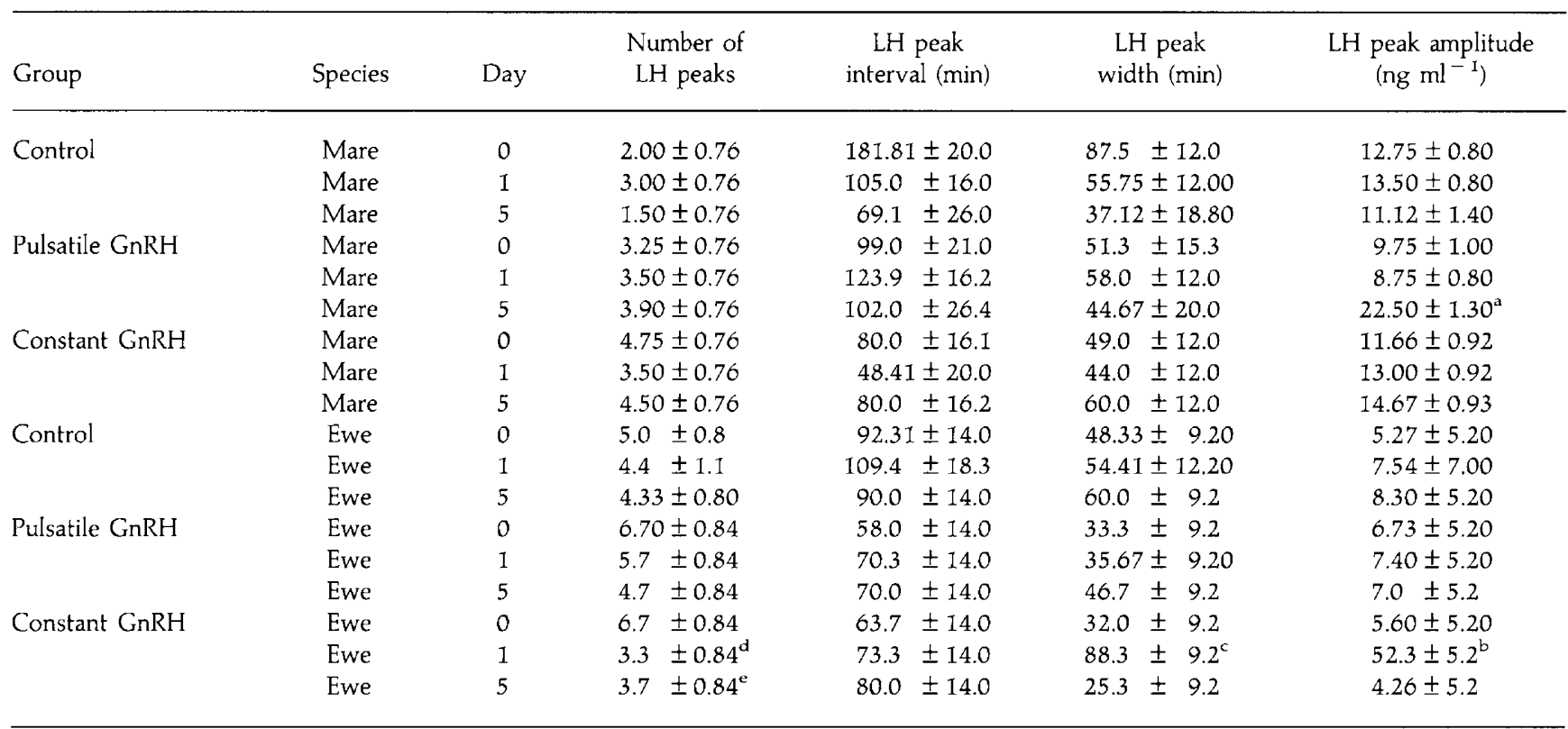

${ }^{a} \mathrm{LH}$ peak amplitude was significantly $(P<0.01)$ increased in mares treated with pulsatile GnRH by day 5 of treatment compared with control mares and mares treated with constant $\mathrm{GnRH}$ on day 5.

LH peak bamplitude and 'width were significantly $(P<0.001)$ higher in ewes treated with constant GnRH on day 1 of treatment compared with those of control and pulsatile GnRH treated ewes on day 1 .

Ewes treated with constant GnRH had significantly fewer LH peaks on day $1(P<0.01)$ and ${ }^{\mathrm{e}}$ day $5(P<0.02)$ of treatment compared with day 0 .

three sampling periods (days $0, I$ and 5). However, mean LH peak amplitude was significantly $(P<0.01)$ higher on day 5 in mares treated with continuous GnRH $\left(25.0 \pm 3.7 \mathrm{ng} \mathrm{ml}^{-1}\right)$ compared with control mares (11.5 $\pm 3.7 \mathrm{ng} \mathrm{ml}^{-1}$ ) (Table 3). Furthermore, LH secretory patterns from representative mares treated with continuous GnRH suggested an increase in basal LH secretion that remained episodic (Fig. 4f).

\section{Discussion}

In mares, endogenous GnRH secretion has been described as 'irregularly episodic' and continuous during oestrus (Grubaugh and Sharp, 1987; Alexander and Irvine, 1987). In addition, studies have characterized the endogenous secretion of $\mathrm{GnRH}$ in mares as being episodic, with secretory events occurring two to three times per $12 \mathrm{~h}$ during dioestrus and increasing in episode frequency during oestrus (Grubaugh and Sharp, 1987; Irvine and Alexander, 1987). GnRH has also been described in mares as continuous throughout the oestrous cycle with intervening secretory events (Alexander and Irvine, 1987). Similarly, LH secretory patterns from representative animals (Fig. 4) suggest that LH secretion is not periodic in mares as it is in ewes. Alternatively, it may be described as having an irregular pattern that occurs regularly. These findings suggest that exogenous $\mathrm{GnRH}$ supplementation in mares may not be restricted to pulsatile administration as described in other mammals, including sheep, primates and humans.

The LH response to constant GnRH in Expt I demonstrated that pony mares responded to constant $\mathrm{GnRH}$ by maintaining increased LH concentrations whereas ewes did not (Fig. Ia,b). Along with persistent high concentrations of LH, mares treated with continuous GnRH had significantly decreased LH amplitudes, suggesting that mares respond to constant $\mathrm{GnRH}$ with increased basal secretion of $\mathrm{LH}$ rather than with larger LH peaks. LH secretion in ewes treated with continuous GnRH was not maintained but rather demonstrated a pattern typical of receptor desensitization or downregulation. This pattern of $\mathrm{LH}$ secretion is similar to the endogenous LH pattern observed in ewes during the preovulatory LH surge (Karsch et al., 1992). Simultaneous measurement of GnRH and LH in ewes by Moenter et al. (1990) indicated an extended GnRH surge accompanied by an LH surge that terminates before cessation of the GnRH surge (Moenter et al., 1990). It has been speculated that termination of the preovulatory LH surge may be due, in part, to depletion of releasable LH from the pituitary and the downregulation of GnRH receptors (Crowder and Nett, 1984). Analysis of LH peaks in ewes treated with continuous $\mathrm{GnRH}$ indicated fewer LH peaks, suggesting the need for pulsatile GnRH administration. Furthermore, LH peak amplitude was increased in ewes treated with continuous $\mathrm{GnRH}$, reflecting an initially large LH secretory response that diminished over time.

In Expt 2, mares treated with pulsatile GnRH had increased plasma LH concentrations on day 5 of treatment $(25 \mu \mathrm{g}$ pulse ${ }^{-1}$ ); however, the same effect was not observed in mares treated with constant $\mathrm{GnRH}\left(25 \mu \mathrm{g} \mathrm{h}^{-1}\right)$. It was hypothesized that the dose of GnRH administered continuously $\left(25 \mu \mathrm{g} \mathrm{h}^{-1}\right)$, derived from studies by Becker and Johnson (1992), may have been insufficient to elicit an $\mathrm{LH}$ response. Analysis of error 

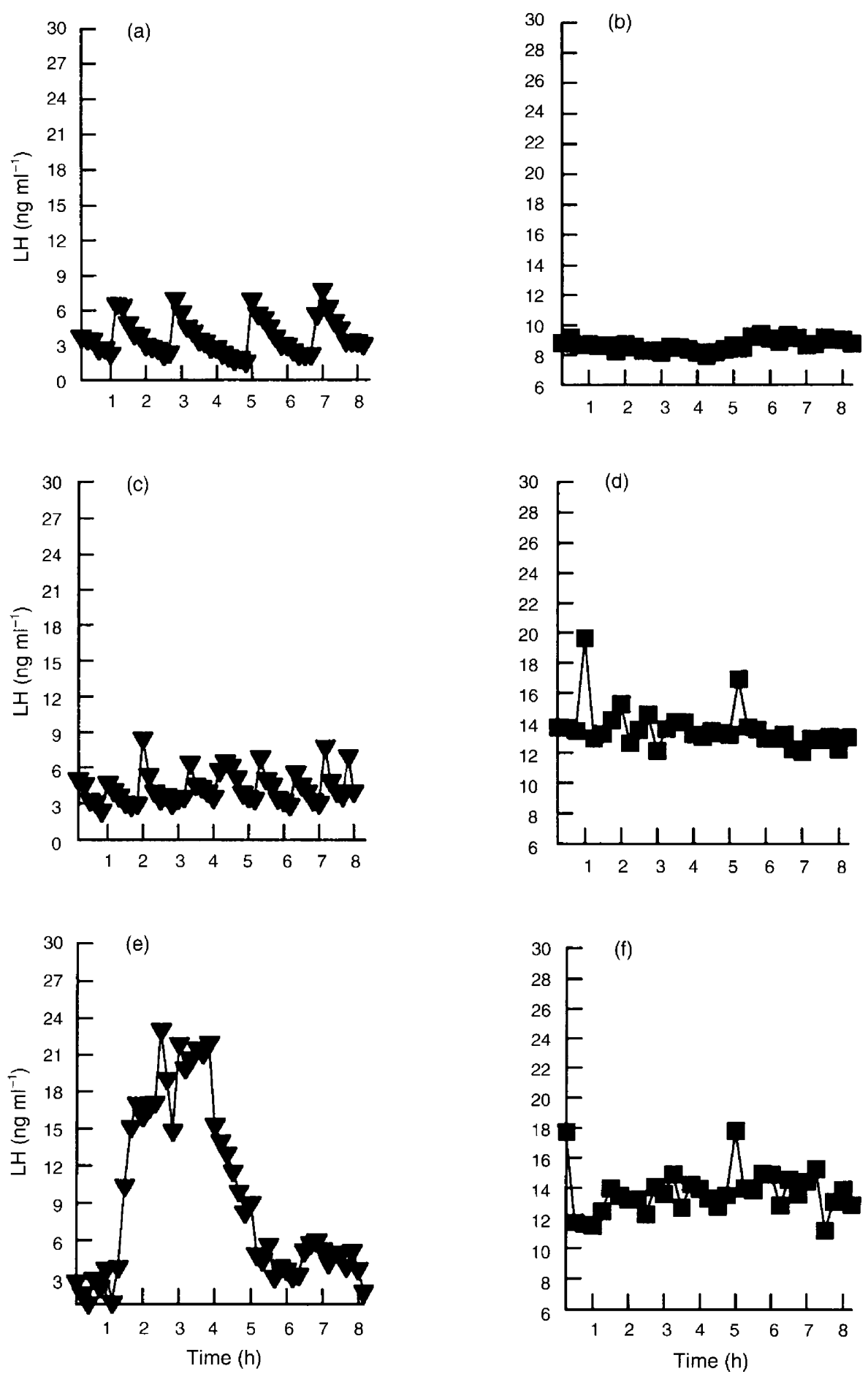

Fig. 4. LH secretory patterns of representative progesterone-treated, ovariectomized mares ( $\square$ ) and ewes ( $\mathbf{V}$ ) from Expts 2 and 3. (a) Control ewe on day 5 (Expt 2). (b) Control mare on day 5 (Expt 2). (c) Pulsatile GnRH-treated ewe on day 5 (Expt 2). (d) Pulsatile GnRH-treated mare on day 5 (Expt 2). (e) Continuous GnRH-treated ewe on day 1 (Expt 2). (f) Continuous GnRH-treated mare on day 5 (Expt 3).

variance in group 2 mares (constant $\mathrm{GnRH}$ ) showed high variance, suggesting a physiological response, although overall mean $\mathrm{LH}$ did not differ.

In Expt 3, plasma LH concentrations on day 5 were increased in mares treated with continuous GnRH (110 $\mu \mathrm{g}$ $\mathrm{h}^{-1}$ ). LH concentrations did not appear to differ between pulsatile GnRH mares in Expt $2\left(17.38 \pm 1.71 \mathrm{ng} \mathrm{ml}^{-1}\right)$ and the constant $\mathrm{GnRH}$ mares in Expt $3\left(20.57 \pm 3.98 \mathrm{ng} \mathrm{ml}^{-1}\right)$. Furthermore, LH peak amplitudes were increased in both groups on day 5 and neither pulsatile GnRH nor constant 
Table 3. Mean $( \pm \mathrm{sD})$ number of LH peaks in $8 \mathrm{~h}$, peak interval, peak width and peak amplitude as determined by ANOVA

\begin{tabular}{|c|c|c|c|c|c|c|}
\hline Group & Species & Day & $\begin{array}{l}\text { Number } \\
\text { of LH } \\
\text { peaks }\end{array}$ & $\begin{array}{c}\text { LH peak } \\
\text { interval (min) }\end{array}$ & $\begin{array}{l}\text { LH peak } \\
\text { width (min) }\end{array}$ & $\begin{array}{l}\text { LH peak amplitude } \\
\left(\mathrm{ng} \mathrm{ml}^{-1}\right)\end{array}$ \\
\hline \multirow[t]{3}{*}{ Control } & Mare & 0 & $3.0 \pm 1.3$ & $93.0 \pm 23.0$ & $97.0 \pm 33.0$ & $9.10 \pm 3.7$ \\
\hline & Mare & 1 & $3.3 \pm 1.3$ & $138.7 \pm 31.0$ & $92.0 \pm 44.0$ & $11.0 \pm 4.0$ \\
\hline & Mare & 5 & $1.7 \pm 1.3$ & $142.4 \pm 31.0$ & $145.0 \pm 33.0^{\mathrm{a}}$ & $11.5 \pm 3.7$ \\
\hline \multirow[t]{3}{*}{ Constant GnRH } & Mare & 0 & $4.5 \pm 1.3$ & $63.0 \pm 20.3$ & $62.5 \pm 28.0$ & $10.2 \pm 3.7$ \\
\hline & Mare & I & $4.0 \pm 1.3$ & $80.75 \pm 20.30$ & $35.2 \pm 28.0$ & $11.5 \pm 3.7$ \\
\hline & Mare & 5 & $2.0 \pm 1.3$ & $103.7 \pm 20.3$ & $63.5 \pm 28.0$ & $25.0 \pm 3.7^{b}$ \\
\hline
\end{tabular}

${ }^{a}$ LH peak width was significantly $(P<0.04)$ higher in control mares on day 5 of treatment compared with mares treated with constant GnRH on day 5 .

${ }^{b}$ LH peak amplitude was significantly $(P<0.01)$ higher in mares treated with constant GnRH on day 5 of treatment compared with control mares on day 5 .

$\mathrm{GnRH}$ affected the number of $\mathrm{LH}$ peaks. The lack of change in the number of $\mathrm{LH}$ peaks, considering the hourly pulses, suggests that the $\mathrm{LH}$ secretory response exceeded the time interval between pulses such that LH secretion increased after the first pulse and remained high through the subsequent pulses. These findings indicate that pulsatile GnRH $(25 \mu \mathrm{g}$ pulse $\left.{ }^{-1} \mathrm{~h}^{-1}\right)$ and constant GnRH infusion $\left(100 \mu \mathrm{g} \mathrm{h}^{-1}\right)$ elicit similar LH secretory responses in progesterone-treated, ovariectomized mares. This supports the conclusions of a study with anoestrous mares in which pulsatile GnRH and constant GnRH infusion (administered by slow release implants) were equally effective in inducing gonadotrophin secretion, follicular growth, ovulation and formation of a corpus luteum (Turner and Irvine, 1991). However, Becker and Johnson (1992) administered pulsatile $\left(20 \mu \mathrm{g}\right.$ pulse $\left.{ }^{-1} \mathrm{~h}^{-1}\right)$ or continuous $\mathrm{GnRH}$ $\left(20 \mu \mathrm{g} \mathrm{h}^{-1}\right)$ to cyclic and anoestrous mares and concluded that continuous GnRH affected plasma concentrations of $\mathrm{LH}$ in a different way to pulsatile GnRH (Becker and Johnson, 1992). The apparent lack of stimulation of LH by continuous GnRH in Expt 2 (current study) and the study by Becker and Johnson suggest an inadequate GnRH dose. The larger dose of continuous $\mathrm{GnRH}$ administered in Expt $3\left(110 \mu \mathrm{g} \mathrm{h}^{-1}\right)$ resulted in a clear increase in LH.

All mares received progesterone throughout the experiment. The LH secretory response in mares receiving GnRH (pulsatile or continuous) was not significant until days 4 and 5 of treatment. In addition, there was a tendency for a reduction in the number of LH peaks by day 5 in control mares, which received no exogenous GnRH. These data suggest that progesterone treatment reduced the pituitary response to exogenous $\mathrm{GnRH}$ in treatment mares and may have suppressed the hypothalamic-pituitary axis in control mares. . Repeated $\mathrm{GnRH}$ administration may have increased the number of pituitary GnRH receptors or the affinity of the receptors to overcome the negative effect of progesterone on the anterior pituitary. Studies in sheep and rats have shown that progesterone can reduce the amount of mRNA encoding $\mathrm{GnRH}$ receptor as well as the number of GnRH receptors (Wang et al., 1988; Laws et al., 1990). In addition, GnRH receptor upregulation has been demonstrated in rats treated with pulses of GnRH (Kaiser et al., 1993). Therefore, it is plausible that a similar mechanism occurs in progesterone-treated, ovariectomized mares.

Plasma progesterone concentrations exceeded $4 \mathrm{ng} \mathrm{ml}-1$ in both dioestrous ewes (Expt 1) and progesterone-treated ovariectomized ewes (control ewes in Expt 2). However, the number of LH peaks (frequency) tended to increase slightly (approximately 1 pulse per $1.5 \mathrm{~h}$ ) in progesterone-treated ovariectomized ewes (control ewes in Expt 2) compared with previously published values ( 1 pulse per $3 \mathrm{~h}$ ) measured in Suffolk ewes (Goodman and Karsch, 1980). The slight variation in number of pulses reported in our study may have been due, in part, to differences among breeds of sheep (Suffolk versus Rambouillet). However, emphasis was placed on the similar concentrations of progesterone between the dioestrous ewes and the progesterone-treated ovariectomized ewes measured in this study, indicating that the progesterone-treated ovariectomized ewes represented ewes during the luteal phase.

In Expt 2 (ewes), LH concentrations differed between ewes treated with continuous $\mathrm{GnRH}$ and controls; however, neither mean LH concentrations nor number of LH peaks differed between ewes treated with pulsatile GnRH $\left(250 \mathrm{ng} \mathrm{h}^{-1}\right)$ and control ewes. Since the rate of $\mathrm{GnRH}$ pulse administration ( 1 pulse $\mathrm{h}^{-1}$ ) was similar to the LH peak frequency measured in the control ewes, the lack of differences in LH secretion between control ewes and ewes treated with pulsatile GnRH was not surprising. These findings emphasize the importance of pulsatile $\mathrm{GnRH}$ administration in sheep to maintain gonadotrophin release. In contrast, LH secretory patterns in ewes treated with constant $\mathrm{GnRH}$ suggest $\mathrm{GnRH}$ receptor downregulation on the basis of the significant increase in LH peak width and amplitude on day 1 , which subsided by the end of day 1 and did not recur through to day 5 .

LH secretory patterns in mares did not reflect changes characteristic of GnRH receptor downregulation or desensitization during any period throughout both experiments. However, data from ewes treated with continuous GnRH in Expts 1 and 2 indicated a decrease in LH release during continuous $\mathrm{GnRH}$ administration that may be due to $\mathrm{GnRH}$ receptor desensitization or downregulation. These findings reaffirm those from a previous study that concluded that GnRH receptor downregulation occurred after exposure to high concentrations of continuous GnRH in ewes (Nett et al., 1981). $\mathrm{GnRH}$ receptor downregulation and a decrease in amount of $\mathrm{LH}$ released has been described in a variety of species during continuous stimulation with exogenous $\mathrm{GnRH}$. In ewes infused continuously with GnRH $\left(2.5 \mu \mathrm{g} \mathrm{h}^{-1}\right)$ for 12 or $24 \mathrm{~h}, \mathrm{GnRH}$ receptor downregulation was observed as $\mathrm{LH}$ concentrations initially rose in response to GnRH infusion and then returned 
to baseline within $5 \mathrm{~h}$ of the onset of GnRH infusion (Nett et al., 1981). Similar results have been observed in ovariectomized ewes (Rippel et al., 1974), pro-oestrous rats (Garner and Blake, 1979) and male rats (Clayton et al., 1985). These studies emphasize the importance of pulsatile GnRH secretion for maintenance of gonadotroph secretion (Knobil, 1980; Levine and Ramirez, 1980; Moenter et al., 1992). The effect of continuous GnRH infusion on GnRH receptor downregulation in horses has not been shown. In one study, over $75 \%$ of anoestrous mares injected subcutaneously with slow release implants designed to release 30 or $60 \mu \mathrm{g}$ of a potent $\mathrm{GnRH}$ analogue for 28 days ovulated within 3-18 days of the start of treatment (Allen et al., 1987). Similar results have been described in other studies using slow release implants containing GnRH (Ainsworth and Hyland 1991; Turner and Irvine 1991). These studies have involved the use of potent GnRH agonists and analogues, and their results have indicated decreased sensitivity to receptor downregulation by gonadotrophs. However, differential binding by potent GnRH analogues and agonists to $\mathrm{GnRH}$ receptors may prevent normal physiological responses by gonadotrophs (Janovick et al., 1993). In addition, no studies have described the gonadotrophic response to natural GnRH administration (pulsatile or continuous) in pony mares. A clear understanding of the response of the pituitary to natural GnRH is necessary for the appropriate use of $\mathrm{GnRH}$ in equine reproduction.

In conclusion, mares appeared to be significantly less sensitive than ewes to extinction of $\mathrm{LH}$ secretion during continuous $\mathrm{GnRH}$ challenge. Pulsatile administration of $\mathrm{GnRH}\left(25 \mu \mathrm{g} \mathrm{h}^{-1}\right)$ and continuous infusion of $\mathrm{GnRH}(100 \mu \mathrm{g} \mathrm{ml}-1)$ elicited similar LH responses in progesterone-treated, ovariectomized pony mares. These findings, together with the irregularly episodic release of $\mathrm{LH}$ in pony mares suggest differences between pony mares and sheep in their gonadotrophic response to administration of natural $\mathrm{GnRH}$. These differences may involve structural differences in the GnRH receptor, distinct second messenger systems or variations in receptor synthesis and recycling. Future work is needed to evaluate structural differences between the ovine and equine GnRH receptor and receptor studies are needed to evaluate receptor kinetics directly.

The authors thank D. Thompson (Louisiana State University) for the ECG anti-serum, J. Roser (University of California, Davis, CA) for the purified equine LH and the National Hormone and Pituitary Program for the ovine LH antibody. Supported in part by USDA Grant no. 9001872 to D. C. Sharp, Florida Agriculture Experiment Station Journal Series Number R-05734.

\section{References}

Ainsworth CGV and Hyland JH (1991) Continuous infusion of gonadotrophinreleasing hormone $(\mathrm{GnRH})$ advances the onset of oestrous cycles in Thoroughbred mares on Australian studfarms Journal of Reproduction and Fertility Supplement 44 235-240

Alexander SL and Irvine CHG (1987) Secretion rates and short-term patterns of gonadotrophin-releasing hormone, FSH, LH throughout the periovulatory period in the mare Journal of Endocrinology 114 351-362

Allen WR, Sanderson MW, Greenwood RES, Ellis DR, Crowhurst JS, Simpson DJ and Rossdale PD (1987) Induction of ovulation in anoestrous mares with a slow-release implant of a GnRH analogue (ICI 118 630) Journal of Reproduction and Fertility Supplement 35 469-478
Becker SE and Johnson AL (1992) Effects of gonadotrophin-releasing hormone infused in a pulsatile or continuous fashion on serum gonadotrophin concentrations and ovulation in the mare Journal of Animal Science 70(4) 1208-1215

Chedrese PJ, Kay TWH and Jameson JL (1994) Gonadotropin-releasing hormone stimulates glycoprotein hormone alpha-subunit messenger ribonucleic acid (mRNA) levels in alpha-T3 cells by increasing transcription and mRNA stability Endocrinology 134 2475-2481

Clarke IJ and Cummins JT (1982) The temporal relationship between gonadotrophin releasing hormone $(\mathrm{GnRH})$ and luteinizing hormone $(\mathrm{LH})$ secretion in ovariectomized ewes Endocrinology 11 1737-1739

Clayton RN, Detta A, Naik SI, Young LS and Charlton HM (1985) Gonadotrophin releasing hormone receptor regulation in relationship to gonadotrophin secretion Journal of Steroid Biochemistry 25(5b) 691-702

Clayton RN (1989) Gonadotrophin-releasing hormone: its actions and receptors Journal of Endocrinology 120 11-19

Crowder ME and Nett TM (1984) Pituitary content of gonadotrophins and receptors for gonadotrophin-releasing hormone $(\mathrm{GnRH})$ and hypothalamic content of GnRH during the periovulatory period of the ewe Endocrinology 114 234-239

Crowder ME, Herring RD and Nett TM (1986) Rapid recovery of gonadotroph function after downregulation of receptors for $\mathrm{GnRH}$ in ewes Journal of Reproduction and Fertility 78 577-585

Dierschke, DJ, Bhattacharya AN, Atkinson LE and Knobil E (1970) Circhoral oscillation of plasma LH levels in the OVX rhesus monkey Endocrinology 87 850-853

Dohlman HG, Thorner J, Caron MG and Lefkowitz RJ (1991) Model systems for the study of seven-transmembrane segment receptors Annual Review of Biochemistry 60 653-688

Garcia MC and Ginther OJ (1975) Plasma luteinizing hormone concentrations in mares treated with gonadotropin-releasing hormone and estradiol American Journal of Veterinary Research 36 1581-1584

Garner LL and Blake CA (1979) Morphological correlates for LHRH self priming and anterior pituitary gland refractoriness to LHRH in proestrous rats: an immunocytochemical study Biology of Reproduction 20(5) 1055-1066

Goodman RL and Karsch FJ (1980) Pulsatile secretion of luteinizing hormone: differential suppression by ovarian steroids Endocrinology 107 1286-1290

Grubaugh WR and Sharp DC (1987) Use of push-pull perfusion technique in studies of gonadotrophin-releasing hormone secretion in mares Journal of Reproduction and Fertility Supplement 35 289-296

Irvine CHG and Alexander SL (1987) A novel technique for measuring hypothalamic and pituitary hormone secretion rates from collection of pituitary venous effluent in the horse Journal of Endocrinology 113 183-192

Janovick JA, Haviv F, Fitzpatrick TD and Conn PM (1993) Differential orientation of a GnRH agonist and antagonist in the pituitary $\mathrm{GnRH}$ receptor Endocrinology 133(2) 942-945

Kaiser UB, Jakubowiak, Steinberger A and Chin WN (1993) Regulation of rat pituitary gonadotrophin-releasing hormone receptor mRNA levels in vivo and in vitro. Endocrinology $133931-934$

Karsch FJ, Moenter SM and Caraty A (1992) The preovulatory surge of gonadotrophin releasing hormone. In Modes of Action of GnRH and GnRH Analogs pp 24I-255 Eds WF Crowley and P Michael Lonn. Springer Verlag, New York

Knobil, E (1980) Neuroendocrine control of the menstrual cycle Recent Progress in Hormone Research 36 53-88

Laws SC, Beggs MJ, Webster JC and Miller WL (1990) Inhibin increases and progesterone decreases receptors for gonadotrophin-releasing hormone in ovine pituitary culture Endocrinology $127373-380$

Lerrant Y, Kottler M-L, Bergamettia F, Moumni M, Blumberg-Tick J and Counis R (1995) Expression of gonadotropin-releasing hormone (GnRH) receptor gene is altered by GnRH agonist desensitization in a manner similar to that of gonadotropin beta-subunit genes in normal and castrated rat pituitary Endocrinology $1362803-2808$

Levine JE and Ramirez VD (1980) In vivo release of luteinizing hormonereleasing hormone estimated with push-pull cannulae from the mediobasal hypothalami of OVX, steroid-primed rats. Endocrinology 107 1782-1791

Moenter SM, Caraty A and Karsch F (1990) The estradiol-induced surge of gonadotropin-releasing hormone in the ewe Endocrinology 127 1375-1384

Moenter SM, Brand RM, Midgley AR and Karsch FJ (1992) Dynamics of gonadotrophin-releasing hormone release during a pulse Endocrinology 130(1) $503-510$ 
Nett TM, Crowder ME, Moss GE and Duello TM (1981) GnRH receptor interaction: $V$ Downregulation of pituitary receptors for $\mathrm{GnRH}$ in OVX ewes by infusion of homologous hormone Biology of Reproduction 24 $1145-1155$

Quirk JF, Hanrahan JP and Gosling JP (1979) Plasma progesterone levels throughout the oestrous cycle and release of LH at oestrus in sheep with different ovulation rates Journal of Reproduction and Fertility 55 15-21

Rippel RH, Johnson ES and White WF (1974) Effect of consecutive injections of synthetic gonadotrophin-releasing hormone on $\mathrm{LH}$ release in the anoestrous and OVX ewe Journal of Animal Science 39(5) 907-914

Santen RJ and Bardin CW (1973) Episodic luteinizing hormone secretion in man: pulse analysis, clinical interpretation, physiologic mechanisms Journal of Clinical Investigation 52 2617-2628

Sharp DC and Black DL (1973) Changes in peripheral plasma progesterone throughout the oestrous cycle of the pony mare Journal of Reproduction and Fertility 33 535-538
Thompson DL, Godke RA and Squires EL (1983) Testosterone effects on mares during synchronization with alrenogest: FSH, LH, estrous duration and pregnancy rate Journal of Animal Science 56 678-686

Turner JE and Irvine CHG (1991) The effect of various gonadotrophin-releasing hormone regimes on gonadotrophins, follicular growth and ovulation in deeply anoestrous mares Journal of Reproduction and Fertility Supplement 44 213-225

Valiquette M, Bonin H, Hnatowich, Caron MG, Lefkowitz RJ and Bouvier M (1990) Involvement of tyrosine residues located in the carboxyl tail of the human beta2-adrenergic receptor in agonist-induced downregulation of the receptor Proceedings National Academy of Sciences USA 87 5089-5093

Veldhuis JD and Johnson ML (1986) Cluster analysis: a simple, versatile, and robust algorithm for endocrine pulse detection American Journal of Physiology 250 E 486

Wang QF, Farworth PG, Findlay JK and Burger HG (1988) Effect of purified $31 \mathrm{~K}$ bovine inhibin on the specific binding of gonadotrophin-releasing hormone to rat anterior pituitary cells in culture Endocrinology 123 2161-2166 